\title{
Chapter 9 \\ When the Expatriate Wife Returns Home: Swedish Women Navigating National Welfare Politics and Ideals of Gender Equality in Expatriate Family Migration
}

\author{
Catrin Lundström
}

\subsection{Introduction}

\begin{abstract}
All the injustice, all the women without pension when they return, for example, with husbands who may have left them, without a cent when they return, who raises those questions? [...] These are the people folks want to forget. And many perhaps think that they have spent... that they have had a luxurious life. [...] And perhaps some of them had (Elise, 70 years old).
\end{abstract}

Social insurance services provided by the Swedish welfare state are primarily based on the contribution of the individual in terms of income and taxation. Such duties and obligations tend to be implicit in the idea of the citizen, further constituting the foundation of 'the Swedish model', including 'the gender equality contract', implemented in Sweden from the 1970s onwards (Hirdman 2002; Lundqvist 2015). Even though the period of 'the great reforms' stems from the 1930s, it was the expansion of a strong public sector - comprising the parliamentary decision on individual taxation in 1971 (within the sphere of the family), subsidised child care, paid parental leave, a national health insurance system and the redistribution of social benefits and rights during the 1960s and 1970s - that paved the way for women's entrance into the labour force (Lundqvist 2015).

These foundational pillars of gender equality in Sweden rest upon rights and responsibilities relative to the welfare system, nurturing an ideal in which (men and women in) the dual-career family share responsibility for care and household work. The same premise characterises the political discussion at large - dealing with the possibilities for women (rather than men) to combine work and family - often with the point of origin in mothers' (and, to a lesser extent) fathers' life puzzle in a heterosexual family, which constitutes the ideal type for gender equality policies in

C. Lundström $(\bowtie)$

Institute for Research on Migration, Ethnicity and Society (REMESO), Linköping University, Norrköping, Sweden

e-mail: catrin.lundstrom@liu.se 
Sweden (Bäck-Wiklund and Bergsten 2010; Lundqvist 2015; Nordenmark 2004). Because of the strong dual-career ideal, there are virtually no discussions about the situation for women whose lives happen to be structured differently.

This chapter is based on interviews with former expatriate wives who returned to Sweden after living as 'trailing spouses' abroad. It asks how they navigate Swedish norms of gender equality in policy and practice upon return. The aim is to discuss how the women's narratives of political and practical ideals formed around work, gender equality, dual income and pension all intersect - and sometimes conflict with notions and idea(l)s of gender, Swedishness and heterosexuality. It is argued that their experiences of expatriate life are related to questions of national identity, gender dependencies and disadvantages in terms of welfare for the women.

Starting from Elise's question (above) about the situation for returning expatriate wives without 'a cent when they return', the chapter discusses the socio-political consequences of the women's economic situation and their gendered dependency, in terms of welfare state policies of redistribution and pension issues. Though it would be utterly incorrect to compare this group of expatriate women with poor pensioners in general - since the women in this study often had access to significant resources such as property, family assets and social capital - their stories do shed light on an existing gap for both migrants and women in general in the Swedish welfare state.

In this manner, questions of emigration and immigration are highlighted, as are issues involving citizenship and gender in relation to equality, welfare and redistribution within the family and society at large. How do expatriate wives navigate market-based solutions abroad - without access to, for example, childcare - and what are the implications for their migration, work and gender equality when they return to Sweden? How do they reflect upon gender, national identity and heterosexual family ideals in this situation?

\subsection{From Gender Equality to Homemaker and Back Again}

The transition from a system built on 'stay-at-home-mums' to the dual-earner household has been crucial for the Swedish model from the 1960s and onwards, at a time when traditional values and ideas about the nuclear family were questioned (Lundqvist 2015). Economic and social independence guided governmental committees at the time, with the goal that women should no longer have to choose between having a job and having children (SOU 1964, 36). In conjunction with this vision, the Swedish state initiated an activation programme to bring women out into the labour force which, in the coming decades, would introduce one million women to salaried labour; women in Sweden would thus proceed from a 'housewife contract' to a 'gender equality contract', in which (primarily) childcare was taken over by state institutions (Hirdman 2002). Carbin et al. $(2017,106)$ argue that homemakers can be defined 'by their absence from the labour market and their presence in a heterosexual marriage'. This is also a dynamic that is centred in the women's narratives, their situation of being an expatriate wife and - at least during this 
period - being located outside the labour force and the relation to issues of work, pensionable income and financial dependence on their husbands.

In contemporary Swedish society, with the dual-earner household and the primacy of salaried work as the core of the welfare state, criticism has drawn attention to how 'employment' is prioritised over the question of how much we actually need to work in a society where productivity is constantly increasing (Paulsen 2010). The feminist critique of the primacy of salaried work points out that women's historical entry to - and 'liberation' through - the labour force during the 1960s and 1970s also meant that the 'housewife norm' was replaced by a 'salaried work standard', where state-run childcare and domestic work would be performed outside, or alongside, salaried labour - a task referred to as 'the second shift' (Carbin et al. 2017, 36; Hochschild 2003). Women still devote a larger amount of time to household work compared to men (Statistics Sweden 2018).

\subsection{Gender and Migration in the Swedish Pension System}

Since two-thirds of my informants were 60 years or older, the pension system is of particular interest for this chapter. The income-related pension system in Sweden is based on three parts: general pension (allmän pension, which includes all kinds of state-financed subsidies through social taxes), occupational pension (tjänstepension, which is income related and paid by the employer) and private savings. Of pivotal importance in relation to gender and migration is the change in the incomerelated pension which, after the 1994 Swedish pension reform, was guided by the 'lifetime-income principle' (Government Bill 1993/94:250). The lifetime-income principle replaced the earlier rules that were based on the best 15 income years of a person's life, which was considered too expensive. This change would disadvantage both those working part-time and those who were periodically located outside the labour force as a result of unpaid (care) work or for other reasons - in other words, primarily women and immigrants (Ekberg and Lindh 2011). ${ }^{1}$ Expatriates are, in general, dependent on their contracts with private companies.

Other parts, such as social assistance or the state-financed guaranteed pension (garantipension) exist to protect those who have earned little or no income during their lives. A state-financed guaranteed pension is based upon income, civil status and the length of residency in Sweden. In order to receive the maximum guaranteed pension (8254 Swedish kronor a month) a person must have resided in Sweden for 40 years, between 16 and 64 years of age. In 2019, every third pensioner - 656,700 people - received a guaranteed pension (Pensionsmyndigheten 2019), four out of

\footnotetext{
${ }^{1}$ Rules and regulations vary due to where the person comes from, in which country s/he has resided as an expatriate, etc. Since women in this study comprise such a heterogeneous group relative to their time abroad and their countries of residence, I cannot account for all possible scenarios in this chapter.
} 
five of whom were women. As we shall see, the guaranteed pension did not, in most cases, cover the situation for the expatriate wives interviewed.

It is, for 'natural' reasons, more difficult for those who immigrated later in life, to earn a pension equivalent to native Swedes within the system of the lifetimeincome principle. Furthermore, immigrants do not have the right to a full guaranteed pension if they have resided in the country for less than 40 years. As Ekberg and Lindh $(2011,38)$ state, there are no simple conclusions to draw in studies between foreign and native-born pensioners but they point out that 'the previous rules for calculating public pension [based on income from work over a 15-year period of time] were more favourable to immigrants than the recent rules [based on the sum of salaried work throughout a person's entire life]'. ${ }^{2}$

Despite the strong focus on gender equality in working life, women continue to dominate the group of poor pensioners in Sweden as they only have 68\% of men's pensions on average (Statistics Sweden 2018, 86). In a pension system mainly based upon salaried work, the well-paid (often men) working full-time for their entire lives are rewarded, whereas those (mostly women) who work part-time or for portions of their lives in poorly paid professions are disadvantaged. This arrangement has a significant meaning for women in general, who spend more time than men doing household work, are more likely to have part-time jobs within the public sector and have structurally lower wages, earning an average of just $76 \%$ of men's wages on a yearly basis (Statistics Sweden 2018); it is of particular importance for the expatriate wives interviewed here.

\subsection{Fieldwork in an All-Women's Network}

The study is based on qualitative interviews, participatory observation and visual methods with women who returned to Sweden after living a shorter or longer period of time abroad. The data are drawn from 46 semi-structured and in-depth interviews with returning Swedish migrant women and participatory observation on 25 occasions over a period of 8 months of fieldwork in four different cities in Sweden during 2014 and 2015. ${ }^{3}$ The women were also asked to draw a map of their social networks, which served both as a basis for discussion and to give an overview of their (perceived) social locations ${ }^{4}$ Most of them had joined various networks for

\footnotetext{
${ }^{2}$ Author's translation.

${ }^{3}$ The interviews were carried out by post-doc Lena Sohl, hired on the project 'To reintegrate Swedishness: The policy of belonging among repatriating Swedish migrant women'.

${ }^{4}$ All material has been rendered anonymous, includes both names of the informants, local chapters, as well as businesses and other information that could be used to identify the informants. The project was approved by the Central Ethical Review Board in Linköping. It follows ethical guidelines and principles for societal research through informed consent, anonymisation and confidentiality within research. Contact information has not been stored together with the transcripts. The women have consented to audio recordings and publication of their transcribed interviews. They
} 
Swedes returning 'home' but they were mainly recruited through the Swedish Women's Educational Association (SWEA) in Sweden, via participation in SWEA's activities and via a snowball method, whereby one informant suggests others. SWEA is a broad international network with around 7000 members worldwide. Although it started as a network for accompanying spouses abroad, some of the largest local branches today are found in Sweden. This is not surprising, since returning Swedes have been one of the single largest immigrant groups in the country for many years. ${ }^{5}$ Originating from the SWEA network resulted in a group dominated by expatriate wives. ${ }^{6}$ The informants were between 33 and 80 years old and had been living in around 30 different countries, in some cases for as long as 45 years.

Participant observation was carried out in SWEA's local chapters and networks in Sweden at lunches, after-work meetings (despite the fact that most of them were not working) and during cultural activities such as theatre visits. Although the transcribed interviews constitute the primary source of analysis, participant observation has offered contextualisation of the interview material and a way to create contacts and trust in the interview situations. This type of 'crystallisation' facilitates the perspective of a research question from different angles in order to reach a more coherent picture of a phenomenon or to discover contradictions within the material (Barbour 1998; Richardson 2000). Potential informants were encouraged to contact researchers voluntarily without being selected by the chairman or other gatekeeper, although this procedure also raises questions about what characterises those who voluntarily choose to participate (Morgan 1998). Certainly, the interviews revealed a general willingness (and, perhaps, need) to speak about issues related to (salaried and non-salaried) work, gender equality and Swedishness.

The fact that the majority of the women had been expatriate wives rather than women with their own careers, coincides with previous studies of Swedes abroad which show that significantly more men have moved abroad due to (their own) employment than have women (Solevid 2016). During the interviews, questions were asked about migration histories, the reasons behind moving home again, relationships (to their spouses), employment, housing, finances, feelings of 'belonging' - both abroad and in Sweden - and about their life situations having returned to Sweden. Through close reading of the transcriptions, some common themes and variations of them within and between the interviews have been identified (Mason 2002).

The majority of women were in their $60 \mathrm{~s}$ and $70 \mathrm{~s}$ at the time of the interviews and maintained a relatively privileged lifestyle following their position abroad as an

\footnotetext{
have been able to choose, throughout the process, whether or not they wanted to answer the questions or discontinue the interview.

${ }^{5}$ This has recently changed after the large wave of immigration due to the war in Syria. In 2018, the largest groups of immigrants were those born in Syria $(14,387)$, Sweden $(12,805)$ and Afghanistan (8093) - see www.scb.se

${ }^{6} \mathrm{~A}$ few did have a career of their own; however, they are not the focus of this chapter. See Lundström (2018) for a more detailed comparison between these groups.
} 
'international' upper-middle or upper-class female. Their lives abroad had been dominated by taking care of the children, domestic work, representation and hospitality in the form of social events and dinners, acting as employers for their domestic workers, volunteering (often in connection with children's activities or school) and participation in the various social activities arranged by SWEA or other social clubs. A small group of women had their own international careers, working mainly for Swedish or international companies or organisations. The age of the women and the fact that they were interviewed after their return to Sweden means that the perspectives in their stories shift - while they look back at their time abroad, they describe their lived present in Sweden. The analysis is thus based on the statements being shaped by the interview situation as such, as a form of situational knowledge in relation to time and space (Haraway 1988).

In many ways, migration did not interrupt the women's structural privileges linked to race or class. However, as the interviews show, this group of white Swedish women holds a central position in maintaining (white) male transnational privilege within the family structure and men's social positions in the new society. At the same time, these family-related privileges also maintained the women's gendered dependence on their husbands, abroad as well as back in Sweden on return.

\subsection{The Transnationalisation of Social Inequality}

The majority of women in this study have - like many other immigrants - been located outside of the Swedish labour force for large periods of their working life, due to the lack of childcare, work permits and other circumstances during the time abroad. These conditions significantly affected their (right to a) pension upon return. As stated, this group of (returning) expatriate wives are not representative of poor pensioners but they equally diverge from the Swedish self-image of a gender-equal society in which women participate in the labour force on equal terms with men (Suter 2019).

One way to situate the women in this study is to proceed from Weiss' (2005) discussion on the transnationalisation of social inequality, in which migrants are positioned in varying ways depending upon their ties and access to 'weak' or 'strong' welfare states. Since migrant populations are located in more than one nation state, Weiss highlights how labour markets, cultural capital and reciprocal relations are increasingly transnational. One aspect of this transnational relationship is that "people often remain socially or symbolically attached to places after they have physically left them' (Weiss 2005, 713) - in this case to the Swedish welfare state.

Weiss (2005) distinguishes the following three social positions in a transnational world society; the transnational upper classes, the middle layers and the lower positions. These actors have significantly different positions within transnational migration, defined by their dependencies and affiliation to different nation states and welfare systems. The women interviewed, who belonged to what Weiss calls the 
transnational upper classes, described themselves as more or less financially independent and, thereby, to a greater extent, independent of the strong Swedish welfare state, as they were not dependent on the guaranteed pension, unemployment benefits or other economic support, yet had access to basic services such as health care as Swedish citizens.

For the middle layers - who are more 'dependent on the national welfare state they are affiliated with' - gaps in the strong Swedish welfare infrastructure were more worrisome (Weiss 2005, 714). They underscored (and at times rediscovered) their dependency on and their trust in the Swedish welfare state, as they often kept their Swedish citizenship while abroad as a guarantee for the future. Many of them believed that they, as Swedish citizens, had rights to a guaranteed pension in Sweden and were often unaware of the requirement of residency in the country. Both cases, however, tend to include a great measure of dependency relative to their husbands. While the women themselves often requested family-oriented political solutions to issues of income redistribution and pension, the chapter raises the connections between the women's condition and broader political issues within the framework of welfare policies and redistribution.

\subsection{Leaving Working Life - And Losing Swedish National Identity?}

Expatriate life involved a different turn compared to those remaining in Sweden. In the absence of work, life seemed passive and 'dull' for many of the informants. This reflects the fact that the choice to work or not rarely seemed to be an entirely individual choice. Rather, it was a question of work permit, childcare and practical circumstances, as 38-year-old Ulrica explained:

Everyone wanted to work but nobody did because you are expected to be at home and take
care of the children and that is a full-time job in itself. [...] You were expected to be a house-
wife. [...] As a woman, I was not accustomed to standing behind my husband. I had a hard
time with that and I was annoyed by it too. [...] The woman should be there and take care
of the children and that is absolutely fantastic in many ways; without the women, the men
could not have done their things. [...] Which is good but, well, I had a hard time with it and
I actually had a hard time with it the whole time.

Leaving professional life is an issue that traverses gender, national identity, the division of labour and heterosexuality. Expressions such as 'You are expected to be at home and take care of the children' reflect Ulrica's view of what a woman is required to do or be - unclear by whom - even if it is contrary to Swedish perceptions of gender equality. In other words, as the family moved out of Sweden, Ulrica saw herself being 'expected' to give up her job and become 'a housewife', thus filling the void of national childcare. While the welfare-state infrastructure was a foundational pillar for women's participation in the labour force, the women in this study 
have been those retreating to the home when these services are no longer available. Despite their age differences, the women had an overwhelmingly consistent picture of their expected duties in the expatriate family.

The women's new roles abroad were described as a prerequisite for the men's lives and careers but, at the same time, they carried a feeling of subordination. On the question of whether the women felt that they had sacrificed something during their stay abroad, they often mentioned the lack of a professional life.

The idea of gender equality in Sweden - in terms of work and dual-earner households - has been intimately associated with a form of national identity or belonging, in addition to a political system (Keskinen et al. 2009); the relationship between gender equality and Swedishness proved to be central to the women's reasoning about work and expatriate life. Having a job and a professional identity was indeed described as a crucial part of the Swedish national identity itself. Since migration is not a clear before-and-after experience but reflects on-going emotional journeys, national ideologies are not something so easily left behind (Ryan 2008). As firstgeneration migrants, they carried with them specific national discourses of gender equality. The interviewed women both identified with and contested the Swedish gender-equality ideology. It was clear that they - as expatriate wives - did not live up to a gender-equal Swedish lifestyle.

When the women visited Sweden during the summer, many of them became aware of the fact that they were not able to transfer the role of an expatriate wife and someone globally privileged - to a Swedish norm of salaried labour, as experienced by Edith (67):

\footnotetext{
When you were home during the summer, you felt a little bit like an alien [...] Everyone talked about their job and job-related things and so on and you... Well, of course you could talk about ... But it felt so silly to talk about... No one was interested in hearing that, because you were expected to talk about job and day-care and all that [...] So this sense of a professional identity disappeared.
}

Being stuck between your 'job and day-care' seems to be the obvious and 'normal' life puzzle for women with young children in the Swedish dual-earner household. For Edith, living a life outside of salaried work appeared to be just 'silly'. Elsa, 70 years old, on the other hand, explains that she has never 'been up for a career' and that she 'liked to be home and putter' - 'I don't like to be stressed and I like to do what I want'. The tendency to reduce care work to "puttering" was also central to the rhetoric of liberating the homemaker during the 1960s (Carbin et al. 2017). Other women argued that, for the first time in their life, they were allowed to see what life could be like outside the realm of salaried employment. For 70-year-old Elise the adjustment to becoming an expatriate wife was dramatic in a positive way:

When we moved to Luxembourg, I was actually at home first, which was just incredible, when suddenly one could choose, when one was not forced to do something. [...] I thought it was nice, if I may be completely honest.

For Elise, the feeling that it was 'nice' not being 'forced to do something' was associated with the sting of a guilty conscience, a feeling of traversing Swedish norms that were taken for granted. Nevertheless, although expatriate wives 
sometimes appreciated life outside salaried work, this economic dependency would follow them through life.

\subsection{To Be a Homemaker: On Subordination and Dependency}

Becoming a 'homemaker' as part of the role of an expatriate wife was often the result of circumstances surrounding residency abroad. Without state-subsidised childcare or a working visa, in a heterosexual marriage that provided the husband with a salary as the breadwinner of the family, in combination with wife-related duties and mothering, the 'stay-at-home mum' became the solution and the prerequisite for the stay abroad as well as for the husband's career, as 75-year-old Maj explains:

I mean, I've been an accompanying spouse to my husband and that involves a lot of work. There was a lot of representation, both at official occasions and at home and there were cocktail parties and dinners and... [...] You have to go through with it. [...] It might sound glamorous to say we had cocktail parties and dinners. [...] But there is a lot required to pull that off.

In addition to representation, Maj describes life as an accompanying spouse as a time-consuming duty: 'You have to go through with it ... There is a lot required' (cf. Arieli 2007; Fechter 2010; Hochschild 1969). Family life in the Swedish genderequality system - based on salaried work - and the conditions for life in an expatriate family thus look fundamentally different. As Fanny, 69 years old, puts it: 'In Sweden you are expected to work, in Brazil you are expected to be at home'. Some women perceived it to be a 'luxury' to be able to live on one salary. While the expatriate wife was in a privileged position abroad, in a community mainly populated by white women dedicated to various gendered duties, it was at the same time associated with dependence and subordination, as Fanny continues:

I had a red line over my name [in the visa], with the word dependencia [dependent] written across it, which means I was financially dependent. So when Amanda [her daughter] would turn 12, she would get such a dash too. And then I said, 'She shall never experience having a red line over her name', so that was one of the reasons why I was pushing for us to go home.

For Fanny, the position as 'dependent' became painfully tangible and impossible to live with when her daughter was given the same status of dependencia as she had herself. In connection to this, her own situation became unbearable and she was now 'pushing' for a move back home again. For others, financial dependence led to a feeling of inequality that was incompatible with a Swedish identity. Tora, 64 years old, says that:

[When I] came to Germany and wanted to start a contract for a cell phone, I couldn't do it, because I was an accompanying spouse [without an income of her own]. It was very hard for me. It was incredibly hard. [...] I did not think about it until I realized that 'Oh dear, here you are like a ...' One belongs to the husband in a completely different way, which I do not like of course. [...] In that sense, I am very Swedish and I want to deal with things myself and be free and I do think, in a way, that people should work. 
Abroad, the women felt limited and curbed in their new position. Tora discovered that she was unable to take on a cell phone contract for herself, which became 'evidence' of her subordinate position. The women's new lives as caregivers in the expatriate heterosexual family also highlight the interrelations between gender, power and globalisation, in which 'the success of global capitalism [is] fundamentally based on sexism' (Fechter 2010, 1281). Structurally, while men have prominent roles in (masculinised) transnational companies, women manage the 'household service' in the (feminised) home (cf. Hearn 2015).

Virtually all the female interviewees described the role of the expatriate wife as associated with a sense of subordination in some way. There was a tension between the fact that they carried with them national ideals of a dual-earner household model based upon gender equality and salaried labour while, at the same time, practically dedicated themselves to unpaid (and perceived as) 'insignificant' care work. The feeling of inequality, subordination and incompleteness was something that the women handled in different ways. Hilda, 67, explains that 'Thankfully I like cooking, and that was the only way I could show that I was good for something [...] but I would rather have had a job that provided a pension'. Others pointed out that gender equality could be upheld by equating different gendered tasks (as an alternative dual-earner model). Still others did various types of non-profit work in order to not appear as dependent wives, especially before they had children. Their strategies show how women in different ways managed the inequality that framed their lives. It was also common to hire an external person, often a migrant woman, to take care of the domestic work, in order to feel less dependent on one's husband and appear less 'un-Swedish' (e.g. Lundström 2012, 2013, 2014). ${ }^{7}$

\section{8 'What Do you Do all Day Long?'}

The women strongly identified with Swedish gender-equality ideals and the feeling of gender inequality was therefore posed in contrast to Swedish norms and values. As Alva, 80 years old, points out, 'all' women work now, 'there are no housewives anymore'. It was also difficult to explain to other Swedes what they occupied themselves with during the day, as Ellen, 59, shows:

People say, like, 'You mean you're not working [gasping] ... but what do you do all the time?' [...] It's pretty strenuous for two people working full-time and having young children and manage everything [...] I don't think I would have had four children if I had lived in Sweden, I do not think so, it would probably have been enough with two, I think.

Basically, Ellen describes care work as something occupying all her time. This raises the issue of both working women's 'second shift' and the work carried out by

\footnotetext{
${ }^{7}$ The international division of labour has been analysed by a number of researchers (Ehrenreich and Hochschild 2003; Gavanas and Calleman 2013; Lundström 2012, 2013; Lutz 2011; Parreñas 2001).
} 
women in public childcare. Had she needed to have a salaried job in Sweden, she would probably have chosen to have fewer children. However, care work, as such, was not seen as credible work by 'Swedes', according to the women. Nathalie, 53 years old, recalls an occasion in Sweden when the question of her professional life came up:

I thought I was someone; but apparently, I am not any longer since everyone else is trying to make me to understand that I am not. [...] Identity issues mean much more than you imagine, because there are so many who comment on my life, in one way or another, when you come home [to Sweden] [...] I don't think that anyone asked me what I did for a living during those two years [abroad]. Here we are so damn quick to ask 'So what do you work with then?' and that is not a positive question - in fact, [what job one has] it is not interesting at all.

Not being able to account for a (professional) life when meeting Swedes was a new experience for Nathalie, who did not come across such questions during her life as an expatriate wife. In her account, Sweden appears to be a country where one is required to have a job and a professional identity in order to 'be someone', in contrast to her life as an expatriate wife in Malaysia. For Nathalie, the lack of a professional identity was a matter of existence. She felt that she 'shrunk' without a job in Sweden. 'I wonder, who am I now?' she says. In this way, the norm of salaried work is a forming system that both augments and shrinks people depending on their location in it. Clara, 43, also describes the summers in Sweden as occasions when she experienced an 'inferiority complex':

It came every summer, every time you went back to Sweden, it came... this inferiority complex [...] which I know many others identify with too. During the summer when you... come home to Sweden on holidays, for example, people ask 'What do you do all day long?' because what I did all day, there is no one in Sweden who can come to terms with that, because it is just luxury, so they say, 'You have no job, you are just floating around'.

It is clear from the quotes that care work itself was not itself considered a job by people in Sweden. It is something that is done without being done. What does Clara actually do 'all day long' without salaried work? The women thus find themselves with the feeling of actually performing a job but without a professional identity. At the same time, it is a fact that women are the ones who perform 'the second shift' in addition to their salaried employment (Hochschild 2003). In this way, expatriate life seemingly presupposes that there are one (or more) women who conduct household work, childcare and representation as their (unpaid) work.

However, the women's stories show that Swedish norms of gender equality tend to become subordinated to gender norms within the framework of the heterosexual family in expatriate contexts. ${ }^{8}$ Although the women feel subordinated and less valuable in their roles as expatriate wives, ideas about Swedishness and gender equality become secondary in relation to the expected ideals of gender and heterosexuality in practice, in the sense that the dual-earner household model no longer functions as

\footnotetext{
${ }^{8}$ The women interviewed who had a career of their own often tuned down the importance of their work in relation to their husbands' (Lundström 2018). They also hired services carried out by a third party, like many expatriate families do when the women do not work (Lundström 2014).
} 
the dominant ideal. Only gender appears to prevail from the gender-equality contract. Indeed, there seems to be a conflict between the absence of a professional identity and explicit ideals of gender equality and Swedishness, although not between mothering and implicit norms of heterosexuality and gender. Apparently, the expatriate wives found themselves snapped back in time between the choice of being a Swedish gender-equal woman or a mother in line with heterosexual gendered norms.

The reasons for returning to salaried work in Sweden were not only economic in nature but a matter of identity and a sense of independence for this group of women. Solveig, 69 years old, explains that 'Many people asked me when I started: "Why are you here ... you do not have to work?" It doesn't have to do with that. [...] You have to feel good about yourself'. Sabine, 68, did not want to accompany her husband without being sure of her work still being there for her when she came back:

Yes, it was very important, because I have never been unemployed, so I absolutely wanted my job. [...] I wanted to be independent as well. [...] I mean, that you are a person of your own, with one's own profession. And not just a housewife. But having your own job, your own thoughts, and your own colleagues and not in need to... It was something that my mother inculcated in me: 'Make sure you have your own profession so that you won't become dependent on your husband'.

Having a job is here linked to a sense of independence and having 'your own thoughts' and 'your own colleagues'. A professional identity is still associated with being a worthy human being in a broad sense and, even further, with a Swedish national identity. This logic reflects both the dual-earner household model and the primacy of the work ideal. In order to be 'someone' and mean 'something', one must have a salaried job. This reasoning became painfully clear upon returning to Sweden.

\subsection{Back to the Future in the Swedish Welfare State}

Although most women saw the opportunity to move abroad as a positive experience that would enrich their lives in many ways, they later realised that they would encounter new situations - in the present as well as in the future. At first, the question of profession and salaried work appeared to be a matter of identity but, arriving back in Sweden, the issue of provision in the Swedish welfare state became an economic issue. The Swedish welfare system did not function in the way they had imagined it would. However, the choice to return did entail an existential dimension in relation to both gender equality and national identity, as Clara, 43, found:

Subconsciously, it was important to move back to Sweden. I felt like I slowly disappeared, it sounds like a big word, but your identity as Swedish ... Women are expected to work ... We are expected to be equal, and to work...

Clara's choice to return to Sweden was rooted in a sense of disappearing as a person abroad. When her professional identity - and thus her identity as 
'Swedish' - was lost, she felt that she 'slowly disappeared'. Returning to Sweden further exposed the women to the practical questions of income, pension and basic security that they had been able to take a break from during their stay abroad. They were now confronted with the Swedish welfare system that did not account for their position as expatriate wives in between different national systems, most overtly with regard to the pension system - which is based on having lived and worked in Sweden (or elsewhere). ${ }^{9}$ They were confronted anew with their positions as heterosexual subjects in a position of dependence. If they had previously perceived their time abroad as expatriate wives as a parenthesis in their lives, they now learned that their migrant history would also define their future. As Laila, 55, puts it: 'I had imagined that there was some sort of basic sum of 7,000 [guaranteed pension] something, for everyone, but that was not the case. If you haven't worked in Sweden, you won't get a [guaranteed] pension, and after all, I hadn't'.

Back in Sweden, it was difficult to re-integrate into society. Nathalie, 53, describes how she had to re-evaluate the meaning of her citizenship:

You had to start thinking about things that I had never thought of before. In the past, I had really felt safe, everything had been arranged, and all of a sudden, it was like... I almost panicked when I realized that I have... I have nothing. If something were to happen, then I would be completely alone, without help from anyone. So you feel a little... Not being welcome home, but a sense of... 'Well, if you are so stupid as to go abroad, then you can have this too', a little bit like that... Pretty much so in relation to both authorities and systems and people and...

If Swedish citizenship constituted a kind of assurance abroad, with the feeling that someone would take care of you when you return home, coming back and realising that no one had prepared a place for you was therefore a shocking insight. In her encounter with the national welfare state, based on salaried labour in the dualearner model, Nathalie found that she was left 'completely alone' with a sense of panic. Fanny, too, explains that it was 'quite difficult' to come back, encountering a welfare system not merely based on Swedish citizenship. As Solveig explains, those who 'lived for many years abroad do not have a good pension when they come home ... and one's self-confidence is not exactly at its height. [...] So, when you are faced with the shock of maybe not getting a job [...] then we sacrifice our experience'.

\subsection{Family-Oriented Privileges and Gendered Dependency}

It is important to point out that the women were located in privileged positions relative to many other migrants, since their husbands in many cases actually could support them. Yvonne, 62 years old, explains that:

\footnotetext{
${ }^{9}$ Pension rules depends upon which country a person has resided and worked in, as well as whether or not $\mathrm{s} / \mathrm{he}$ has refugee status.
} 
I never worried about that, but I do know that I don't have any pension to talk about, basically nothing but we have thought about that in the family, so I will probably manage anyway...

Not having a pension 'to talk about' does not seem to worry Yvonne. Without a pension of one's own, the women remained dependent on their husband's pensions (or allowances) and their good will. Birgit, 77 years old, explains that she does not worry too much about it either:

My husband has a good pension, he has a great pension, but if he should pass away or pass on as you say, then I must ... I won't be able to live in this house, for example [...] No, it won't work, so in that case I have to sell everything. But that's the way it is for most people.

Without her husband's support, Birgit no longer sees herself being able to afford the house she lives in. As for 75-year-old Maj, safety is conditional on her marriage and the fact that her husband was alive:

I do feel safe because of our private savings, quite frankly. But if I were alone ... then I'd need to have some saved capital to live on, because I can't live on this pension.

Maj and Yvonne present themselves as independent subjects, relative the nation state, due to their private assets and savings. Like the transnational upper classes in Weiss' (2005) analysis, they perceive themselves as relatively independent with regard to the welfare state. However, regardless of their (perceived) independence from the state, their provision was in most cases dependent on their continued marriage. Hence, such safety was often conditioned by their husbands and/or their possible generosity.

Through their husbands, Yvonne, Birgit and Maj, like other women, had access to significant economic and social privileges. Their white upper-middle-class privileges were, however, as Phyllis Palmer $(1989,16)$ formulates it, 'integrally linked to their subordinate relations with white men'. Family-related privileges thus maintain their class and racially structured positions, yet through a gendered dependency, in the present, as well as in the future. Nadja, 46, explains this:

I have had no private pension savings in Sweden over these 11 years, so it is like a hole that is very noticeable, really $[\ldots]$ as an effect of our mobility.

In addition to the feeling of insufficiency, there was an underlying concern for a possible divorce. Ellinor, at 61, realised that she could not afford a divorce: 'I don't have the resources'. The women who had divorced were obliged to ask other family members for financial help. Forty-year-old Stella's dependency on her husband only became apparent after their divorce:

We had a joint pension fund so that half of the money ... but when we divorced, my part was frozen [until retirement age], so I have it, but I can't draw on it - the money is still there.

Sigrid, 54, says that when she looks back on her stay abroad:

I regret it, because it is more fun to work as a civil engineer, you make money and have a fun job but, at the same time, I have had a very good life with our children and we always had a stable financial situation since he had a good international position and earned very well. 
Sigrid reflects on what she sacrificed while being at home with 'our children' and concludes that she gave up 'money' and 'a fun job'. Today, Sigrid is divorced and has moved away from her husband; she explains that 'I have no right to the salary, but I still get [an allowance] thanks to his good will' - precisely, the kind of dependency that the Swedish welfare state is structured to avoid.

Their location between heterosexual family norms and working ideals affected the women's political views. The issue of individual taxation, which has been a matter of course for Swedish policies of gender equality, was perceived as a hindrance for them. Elisabeth, 45 years old, now argues that 'it might not be so bad with joint taxation, [it is] actually a kind of work to take care of a family and children'. Signe, 70 years old, on the other hand, thought that 'perhaps it should be more natural to be at home and take care of young children for a longer period of time'. Suddenly, the Swedish gender-equality policy and dual-earner model appeared as an individual loss for them, as Elise, 70, says:

We did not get any pension credits when we moved [...] but if you live in a country where you get at least part of your husband's pension... That is impossible to say in Sweden. Then people go mad [...] 'But what if you have lived your whole life together, shouldn't you share your pension?'

From their perspective, men should not be able to choose whether or not they share their income and pension with their spouse. Without the right to a guaranteed pension then a generous spouse, a family fortune, an inheritance or a loan became the salvation for women. In the light of these circumstances, these women perceived a joint (family and marriage-based) taxation system to be more advantageous. When looking at the family as a unit, 'the income pooling [...] enables the household to be perceived as a unit with unitary interests, despite the very different relationships to production of its separate members' (Hartmann 1981, 374). However, are pension issues and income distribution in relation to gender and migration merely a family issue?

\subsection{Conclusions}

This chapter has examined the experiences of returning migrant women and their negotiations of gender (in)equality, work and national identity in expatriate families caught between different market-based systems abroad and the national welfare system in Sweden. In many ways, the women's work enabled their husbands' careers and expatriate life and family. The women were thus located between a heterosexual family norm (in which women continue to take the primary responsibility for children) and the Swedish model of gender equality (in which women and men are co-equal individuals in a dual-earner household relative to the services that the welfare state provides). Upon migration, the ideals of the dual-earner household model were not transferred into new contexts and situations. When the welfare state withdrew, the women in this study had to fill the void. 
On the one hand, the women said that they were 'expected' to be flexible actors in a global market and, at least indirectly, willing to give up a career for their husband's jobs in Swedish (or transnational) companies abroad. On the other hand, redistribution in the national welfare state is organised on the principle of residency and labour conducted within the country. As a solution to this situation, the women requested a policy of joint taxation, organised to fit their roles as global actors in a heterosexual family norm.

Could their situations be perceived differently? The outcomes of Swedish gender-equality policy continue to disadvantage female pensioners, who work parttime to a greater extent than do men. At the same time, immigrants have difficulty in receiving an acceptable pension - and living standard - during their time in Sweden (Ekberg and Lindh 2011). These women's stories reveal the shared vulnerability of both these groups and problematises 'taken-for-granted' conflict lines between Swedish citizens and migrants.

If the guaranteed pension is a basic protection, questions raised are perhaps why residency should matter for the care work (in this case) that is carried out. If the opportunity (for Swedish men) to move and work abroad (for Swedish or international companies) is dependent on unpaid care work (conducted by women as 'trailing spouses'), it may be reasonable to ask what the principles of redistribution should look like. In this case, there are both similarities and differences between the various immigrant groups. While Swedish citizens (foreign- or native-born) residing in Sweden are entitled to a guaranteed pension, regardless of whether they have worked or not, Swedish citizens living and working abroad are generally left to agreements with a private employer. Which parts of the welfare system should (foreign- or native-born) Swedish citizens then be entitled to and on what principles should these rights and distribution be based? For Swedish citizens with an immigrant background, the question arises as to how to adjust their lives retroactively. How can those who migrated to Sweden later in life have the opportunity to have a full working life in accordance with the principle of a lifetime income?

Expatriate wives certainly make a choice when they move abroad with their husbands. Yet their experiences clearly challenge Sweden's ideal of gender equality, where men and women share salaried work. This raises a number of questions for further research: Why do women continue to sacrifice their careers for their husbands' careers and what does this reveal about gender norms in Sweden in relation to political ideals of equality? What is expected from citizens and actors in a globalised labour market and economy and how should a national welfare system adjust to these requirements? Who benefits and who is disadvantaged in the current globalised labour market?

Acknowledgements The study 'Re-integrating Swedishness: The politics of belonging among returning Swedish migrant women' was financed and thus made possible by the Swedish Research Council, dnr. 421-2013-900. 


\section{References}

Arieli, D. (2007). The task of being content: Expatriate wives in Beijing, emotional work and patriarchal bargain. Journal of International Women's Studies, 8(4), 18-31.

Bäck-Wiklund, M., \& Bergsten, B. (2010). Det moderna föräldraskapet. En studie av familj och kön i förändring. Stockholm: Natur \& Kultur.

Barbour, R. S. (1998). Mixing qualitative methods. Quality assurance or qualitative quagmire. Qualitative Health Research, 8(3), 352-361.

Carbin, M., Overud, J., \& Kvist, E. (2017). Feminism som lönearbete. Stockholm: Leopard förlag.

Ehrenreich, B., \& Hochschild, A. R. (2003). Global woman. Nannies, maids and sex workers in the new economy. New York: Metropolitan Books.

Ekberg, J., \& Lindh, T. (2011). Pensionsreformen och invandrarna. Ekonomisk Debatt, 39(5), 33-40.

Fechter, A.-M. (2010). Gender, empire, global capitalism. Colonial and corporate expatriate wives. Journal of Ethnic and Migration Studies, 36(8), 1279-1297.

Gavanas, A., \& Calleman, C. (2013). Rena hem på smutsiga villkor? Hushållstjänster, migration och globalisering. Göteborg/Stockholm: Makadam.

Government Bill 1993/94:250. (1993). Reforming the general pension system. Stockholm: Regeringskansliet.

Haraway, D. (1988). Situated knowledges. The science question in feminism and the privilege of partial perspective. Feminist Studies, 14(3), 575-599.

Hartmann, H. (1981). The family as the locus of gender, class and political struggle: The example of housework. Signs, 6(3), 366-394.

Hearn, J. (2015). Men of the world. Genders, globalizations, transnational times. London: Sage.

Hirdman, Y. (2002). Genus. Om det stabilas föränderliga former. Stockholm: Liber.

Hochschild, A. (1969). The role of the ambassador's wife: An exploratory study. Journal of Marriage and the Family, 31(1), 73-87.

Hochschild, A. R. (with Machung, A.) (2003). The second shift. London: Penguin Books.

Keskinen, S., Tuori, S., Irni, S., \& Mulinari, D. (2009). Complying with colonialism. Gender, race and ethnicity in the Nordic region. Farnham, UK: Ashgate.

Lundqvist, Å. (2015). Activating women in the Swedish model. Social Politics: International Studies in Gender, State and Society, 22(1), 111-132.

Lundström, C. (2012). 'I didn't come here to do housework'. Relocating 'Swedish' practices and ideologies in the context of the global division of labour: The case of expatriate households in Singapore. Nordic Journal of Migration Research, 2(2), 150-158.

Lundström, C. (2013). 'Maid' sökes. Live-in-maids och skillnadsskapande praktiker i svenska migranthem i Singapore. In A. Gavanas \& C. Calleman (Eds.), Rena hem på smutsiga villkor? Hushållstjänster, migration och globalisering (pp. 107-126). Stockholm/Göteborg: Makadam.

Lundström, C. (2014). White migrations: Gender, whiteness and privilege in transnational migration. Basingstoke: Palgrave.

Lundström, C. (2018). Hemmafru hemma: Återvändande migrantkvinnors möte med svenska jämställdhetsnormer i politik och praktik. Sociologisk Forskning, 55(2-3), 389-414.

Lutz, H. (2011). The new maids. Transnational women and the care economy. London: Zed Books.

Mason, J. (2002). Qualitative researching. London: Sage.

Morgan, D. L. (1998). Planning focus groups. Focus group kit 2. Thousand Oaks: Sage.

Nordenmark, M. (2004). Arbetsliv, familjeliv och kön. Umeå: Boréa.

Palmer, P. (1989). Domesticity and dirt. In Housewives and domestic servants in the United States 1920-1945. Philadelphia: Temple University Press.

Parreñas, R. S. (2001). Servants of globalization: Women, migration and domestic work. Stanford: Stanford University Press.

Paulsen, R. (2010). Arbetssamhället. Hur arbetet överlevde teknologin. Malmö: Gleerups.

Pensjonsmyndightenen. (2019). Korta pensionsfakta [Short pension facts]. https://www.pensionsmyndigheten.se/nyheter-och-press/pressrum/kortapensionsfakta. Accessed 15 Sep 2020. 
Richardson, L. (2000). Writing. A method of inquiry. In N. K. Denzin \& Y. S. Lincoln (Eds.), Handbook of qualitative research (2nd ed., pp. 923-949). Thousand Oaks: Sage.

Ryan, L. (2008). Navigating the emotional terrain of families 'here' and 'there': Women, migration and the management of emotions. Journal of Intercultural Studies, 29(3), 299-313.

Solevid, M. (2016). Svenska utlandsröster. SOM-undersökningen till utlandssvenskar 2014. Göteborg: SOM-institutet.

SOU. (1964). Ökat stöd till barnfamiljer. Promemoria avgiven av familjeberedningen. Stockholm: Socialdepartementet.

Statistics Sweden. (2018). Women and men in Sweden 2018: Facts and figures. Stockholm: SCB.

Suter, B. (2019). Migration as adventure: Swedish corporate migrant families' experiences of liminality in Shanghai. Transitions: Journal of Transient Migration, 3(1), 45-58.

Weiss, A. (2005). The transnationalization of social inequality: Conceptualizing social positions on a world scale. Current Sociology, 53(4), 707-724.

Open Access This chapter is licensed under the terms of the Creative Commons Attribution 4.0 International License (http://creativecommons.org/licenses/by/4.0/), which permits use, sharing, adaptation, distribution and reproduction in any medium or format, as long as you give appropriate credit to the original author(s) and the source, provide a link to the Creative Commons license and indicate if changes were made.

The images or other third party material in this chapter are included in the chapter's Creative Commons license, unless indicated otherwise in a credit line to the material. If material is not included in the chapter's Creative Commons license and your intended use is not permitted by statutory regulation or exceeds the permitted use, you will need to obtain permission directly from the copyright holder. 